\title{
Cultivating narratives: Cultivating successors - A reply to Steiger et al.
}

\author{
Hannah Chiswell \\ Centre for Rural Policy Research, Exeter University
}

Submitted December 12, 2012 / Published online March 27, 2013

Citation: Chiswell, H. (2013). Cultivating narratives: Cultivating successors — A reply to Steiger et al..

Journal of Agriculture, Food Systems, and Community Development, 3(2), 25-28.

http://dx.doi.org/10.5304/jafscd.2013.032.016

Copyright (C 2013 by New Leaf Associates, Inc.

The paper in this journal, Cultivating Narratives: Cultivating Successors, by Steiger, Eckert, Gatrell, Reid, and Ross (2012),continues to develop an underresearched and increasingly relevant topic, particularly given the benefit many commentators believe is to be derived from "effective succession," in terms of the delivery of the food security agenda (Lobley, Baker, \& Whitehead, 2010). Although Steiger and colleagues make an important empirical contribution to our understanding of succession - a topic that, despite its prevalence, we know surprisingly little about (Dyck et al, 2002; Lobley \& Baker, 2012) — I remain troubled by their uncritical acceptance that small farming is sustainable, their use of the term "small family farm," their equivocal definition of the "successor," and their failure to understand the nature and purpose of Gasson and Errington's typology. This

Centre for Rural Policy Research, College of Social Sciences \& International Studies, Exeter University Amory Building, Rennes Drive, Exeter, Devon, EX4 4RJ, United Kingdom; H.M.Chiswell@exeter.ac.uk brief note offers an opportunity to explore these points, which I hope offers a vehicle through which researchers can continue to engage with, and refine understanding of, the increasingly important topic of intergenerational farm succession.

Steiger et al. begin their discussion by posing the age-old question "why save the family farm" and continue by suggesting there are "at least three reasons to be concerned" (p. 90) about its future, including sustainability, food security, and demographics.

They claim that "stewardship" is "a value inherent to the small family farm" (p. 90). This is somewhat problematic, as while evidence does suggest "more conservative, traditional values of 'leaving the land better than you found it' and 'preserving the beauty of the countryside"" are "regarded more highly by small family farmers" (Gasson, 1974, p. 131), this greater inclination toward conservation does not necessarily translate into action. For example, in a survey of 504 British farms in 1993, only 6 percent of very small farms $(<49$ acres or $20 \mathrm{ha})$, and 10 percent of small farms 
(49-124 acres or 20-50 ha) were enrolled in an agri-environmental scheme, compared with 44 percent of large farms (>494 acres or $200 \mathrm{ha}$ ) (Lobley, 2000). The debate surrounding the value of small farms is wide and the complexities of the debate are explored in greater detail elsewhere (see Lobley, 1997; 2000, Potter \& Lobley, 1996); the point I wish to convey is that one cannot simply assume "stewardship" is "a value inherent to the small family farm" (Steiger et al., 2012, p. 90) when in reality it "appears to be a clustering of attributes, some behavioral, others situational, that contributes to a farm's conservation value" (Lobley, 2000, p. 600). To assume otherwise, as Steiger et al. (2012) do, simply undermines their argument.

It is neither my intention to question nor discredit the value of the small family farm. On the contrary, I am a strong advocate of the family farm, particularly in the context of the incipient but nonetheless totemic food security challenge. It is refreshing to see Steiger et al. also note the importance of the family farm in delivering food security; they effectively describe the food security challenge, recognizing that achieving "food security goes beyond food availability to also encompass agricultural diversity, regional prosperity, environmental integrity, biodiversity, and the predictability and fairness of the system of production, sale and delivery" (p. 90). Steiger and colleagues continue by noting the difference in food security between the developing world and the nutritionally poor North and propose that "fresh foods are more nutritious, and fresh foods are more likely delivered locally by smaller family farms" (p. 90, emphasis added). This statement is problematic in two ways. Firstly, despite popularization of the notion that local foods are more nutritious, it is widely observed that all the factors affecting nutritional quality of produce, including production method, post-harvest handling, storage, processing, and packaging, apply equally to produce that is produced locally or elsewhere. While Steiger et al.'s claim mirrors calls from advocates of local food "to reappraise the role of local food... in terms of its potential to integrate the needs of environmental sustainability, nutrition and social justice" (Kirwan \& Maye, 2013, p. 6), it is a simplistic and unsupported supposition that fuels the false dichotomy between "local- good" and "global-bad," and ignores appeals in the literature to view the value of local food systems in the context of careful evidence-based research (Coley, Howard, \& Winter, 2009; Winter, 2003). Secondly, Steiger et al. further confound this qualification by stating that nutritious foods are more likely to be delivered by smaller family farms; this authoritatively implies that the smaller the family farm, the fresher and therefore more nutritionally rich the produce is, yet I am aware of no evidence to support this notion. I therefore ask Steiger and colleagues, what they mean by the small family farm? I also propose they are actually referring more generally to the "family farm," a term which often, and wrongly, implies a smaller farm. In addition, I suggest that the concept of "familiness," as offered by Lobley and Baker (2012), defined as the close link between family and business, would be more fitting. Although not explicitly linked to nutritional benefits, familiness is associated with a host of benefits, including the transfer of firmspecific knowledge and detailed knowledge of the farm, including its microclimate and idiosyncrasies, which are important benefits given the proclaimed need to sustainably "exploit spare capacity in farming" (Potter, 2009, p. 53).

Steiger et al. continue conveying their concern for the small family farm by pronouncing with considerable authority that "young people are not farming" (p. 90). This claim again neglects the wealth of literature that debates the supposed "crisis in succession." Although, as revealed by Lobley, Baker, and Whitehead (2010) in their international comparison of succession and retirement patterns, U.S. states had lower rates of succession compared with England and Canada, this does not categorically show that "young people are not farming," with the percentage of respondents identifying a successor ranging from 26 to 32 percent across the five U.S. states in the survey.

Although Steiger and colleagues derive benefit from interviews with both "current farmers who had inherited the farm" and "likely future successors," providing what they describe as a "threegeneration view of some of these farms" (p. 96), I believe that given the varying political, economic, and cultural contexts that would have influenced these different generations, the experience of one 
generation of successors is likely to have differed, perhaps significantly, from the next. This distinction is more than a convoluted semantic debate, and serves to highlight the "successor" and the "likely future successor" represent different generations who are likely to have contrasting experiences of the succession process.

As Whitehead, Lobley and Baker (2012, p. 314) summarize, "the economic, social and environmental setting for farming businesses has changed dramatically in the last three decades," and so will the experiences of the "successor" and the "likely future successor." Conflating the experiences of current "successors" with "likely future successors," as Steiger et al. do, also fails to recognize the "likely future successor" as an autonomous actor and highlights their reprehensible absence in the wider succession literature. The successor remains the subject of "passing references, most commonly framed through the words of parents" (Riley, 2009, p. 246), despite empirical work by Riley (2009) which highlighted that, even as children, future successors are powerful and active actors with distinctive experiences and narratives.

Steiger et al. recognize there is "much scholarly research on farm succession" (p. 96), including categorization of the outcomes of succession and/or the process. They directly refer to a typology offered by Lobley, Baker, and Whitehead (2010). However, the typology Steiger and colleagues refer to is actually Gasson and Errington's (1993) "four ideal types," which is accompanied by a comprehensive account, and is merely referred to by Lobley, Baker, and Whitehead, rendering much of the ensuing criticisms from Steiger et al. unnecessary as these had been explicated in the original literature. Steiger et al.'s main criticism, that "the process and types of successors may not be as clean as suggested by Lobley, Baker and Whitehead" (p. 96), is undoubtedly valid, but fails to take heed of Gasson and Errington's original typology and literature, in which they repeatedly stress they only intended to "represent ideal types" (1993, p. 206). Steiger and colleagues outline each succession type in turn, illuminating the examples with a series of verbatim quotes that follows through on their intention to "listen to" and "respect" the farmer as the "expert on his or her experiences of the situa- tion" (p. 93). They then return to the inadequacy of the typology and suggest how some succession routes reflect a "combination" of the ideal routes and how some successor routes "defy the categorization suggested by Lobley, Baker and Whitehead (2010)" (p. 97). In doing so it would seem that Steiger and colleagues have failed to engage with the founding literature, and literature that in anticipation of these criticisms clearly emphasizes how "in reality, the patterns of succession are many and varied and each may have some element of more than one ideal type" (Gasson \& Errington, 1993, p. 206). This is not to deny that some succession routes may lie outside the categorization, but as the literature surrounding the "four ideal types" makes clear, they were never intended or expected to capture every empirically observable succession route. In the context of Gasson and Errington's work, Steiger et al.'s criticisms of what they refer to as Lobley, Baker, and Whitehead's typology are unnecessary and ultimately detract from the intrinsic value of their empirical findings, which appear to be used to prove the typology wrong, rather than contribute to scholarly understanding of succession.

Steiger et al. found that six out of 16 farmers in their study fit the "farmers boy" type, but continue by claiming "some of the 'farmer's boys' show good business and managerial skills and high motivation" (p. 99) and "do not seem to be as unwilling to change and incorporate new business strategies as Lobley, Baker, and Whitehead (2010) fear" (p. 102). The surprising level of business and managerial skills, as well as the pleasing level of motivation of the "farmer's boy" is a potentially important finding, particularly in the context of the multitude of contemporary challenges facing the industry, and it warrants further discussion; why were these potential successors showing surprising levels of business and managerial skills? The discussion of gender interestingly revealed that "wives were active partners in the business" who brought "good business and managerial skills, motivation and creativity to the operation" (p. 99) and made up for the inadequacies of the "farmer's boys." This is an important conclusion and I ask Steiger and colleagues, in policy and extension terms, what could this mean? 
Despite producing a wealth of "both surprising and illuminating" results (Steiger et al., 2012, p. 102), and responding to the "need to develop a clearer understanding of the process of intergenerational transfer in countries across the globe" (Lobley, Baker and Whitehead, 2010, p. 61), the main conclusion of Steiger and colleagues' research curiously remains concerned with how their "oral history data did not completely fit with the succession categories" (p. 102). Although they uncritically assert that small farming is sustainable, conflate the experiences of the successor with the likely future successor, and purvey an incomplete view of the literature by neglecting the work of Gasson and Errington (1993) as longstanding observers of the family farm, implicit throughout the article is an enduring and relevant belief that the adequacy of the transfer of managerial control can make a genuine contribution in rising to the "challenges of the future" (Lobley et al., 2010, p. 60). As aptly stated by Potter and Lobley, "in the patterns of succession today can be read the shape of farming futures to come" (1996, p. 305); the intentions of potential successors, and transfer arrangements in place, will undoubtedly shape farming futures. As the global population is set to reach 9 billion by midcentury, and demand for food is expected to grow by up to 70 percent, it is perhaps now, more than ever, we need to strive for a more rigorous and detailed understanding of the process of succession. It is, however, paramount that future research strives to make an accurate and well supported case for the family farm, appreciates the uniqueness of the pressures influencing the succession process at this time, and engages with and builds on foregoing literature.

\section{References}

Coley, D., Howard, M., \& Winter, M. (2009). Local food, food miles and carbon emissions: A comparison of farm shop and mass distribution approaches. Food Policy, 34(2), 150-155. http://dx.doi.org/10.1016/j.foodpol.2008.11.001

Dyck, B., Mauws, M., Starke, F. A., \& Mischke, G. A. (2002) Passing on the baton: The importance of sequence, timing, technique and communication in executive succession. Journal of Business Venturing, 17(2), 143-152. http://dx.doi.org/10.1016/S08839026(00)00056-2
Gasson, R. (1974). Socio-economic status and orientation to work: The case of farmers. Sociologia Ruralis, 14(3), 127-141. http://dx.doi.org/ 10.1111/j.1467-9523.1974.tb01020.x

Gasson, R. \& Errington, A. (1993). The farm family business. Wallingford, UK: CAB International.

Kirwan, J., \& Maye, D. (2013). Food security framings within the UK and the integration of local food systems. Journal of Rural Studies, 29, 91-100. http://dx.doi.org/10.1016/j.jrurstud.2012.03.002

Lobley, M. (1997). Small-scale family farming and the environment: The contribution of small farms to the management of conservation capital of the British countryside (Unpublished doctoral dissertation). Wye College, University of London.

Lobley, M. (2000). Small-scale family farming and the stock of conservation capital in the British countryside. Farm Management, 10(10), 589-605.

Lobley, M., \& Baker, J. R. (2012). Succession and retirement in family farm businesses. In M. Lobley, J. R. Baker, \& I. Whitehead (Eds.), Keeping it in the family: International perspectives on succession and retirement on family farms (pp. 1-20). Surrey, UK: Ashgate.

Lobley, M., Baker, J. \& Whitehead, I. (2010). Farm succession and retirement: Some international comparisons. Journal of Agriculture, Food Systems, and Community Development, 1(1), 49-64. http://dx.doi.org/10.5304/jafscd.2010.011.009

Potter, C. (2009). Agricultural stewardship, climate change and the public goods debate. In M. Winter \& M. Lobley (Eds.), What is land for? The food, fuel and climate change debate (pp. 247-263). London: Earthscan.

Potter, C., \& Lobley, M. (1996). Unbroken threads? Succession and its effects on family farms in Britain. Sociologia Ruralis, 36(3), 286-306. http://dx.doi.org/10.1111/j.1467-9523.1996. tb00023.x

Riley, M. (2009). "The next link in the chain": Children, agri-cultural practices and the family farm. Children's Geographies, 7(3), 245-260. http://dx.doi.org/10.1080/14733280903024407

Steiger, T., Eckert, J., Reid, N., \& Ross, P. (2012). Cultivating narratives: Cultivating successors. Journal of Agriculture, Food Systems, and Community Development, 2(2), 89-105. http://dx.doi.org/10.5304/jafscd.2012.022.012

Winter, M. (2003). Embeddedness, the new food economy and defensive localism. Journal of Rural Studies, 19(1), 23-32. http://dx.doi.org/10.1016/S0743-0167(02)00053-0 